\title{
Finnish records of discomycetes: Cudoniella viridula and a new species of Orbiliaster
}

\author{
SEPPO HUHTINEN
}

\begin{abstract}
HUHTINEN, S. 1992: Finnish records of discomycetes: Cudoniella viridula and a new species of Orbiliaster. - Karstenia 32:61-64.

Cudoniella viridula Grelet, formerly known only from the type collection from France, has been re-collected and an emended description is given. Study of the holotype showed that the type contains no mature apothecia. A potential earlier name, Helotium proximellum P. Karst. is best treated as a nomen dubium. A new species, Orbiliaster paradoxa, is described. The type of the genus Orbiliaster Dennis, O. pilosa, is re-examined and the description emended.
\end{abstract}

Key words: Ascomycetes, Cudoniella viridula, Finland, Orbiliaster, taxonomy

Seppo Huhtinen, Department of Biology, University of Turku, SF-20500 Turku, Finland

The two rarities (Ascomycetes: Leotiales) treated in this paper were collected in SW Finland. Neither the substrates nor the sites were in any way special, but the inconspicuousness of these fungi may explain the minimal amount of collections. The descriptions given below are based on dead herbarium specimens and unfortunately do not meet the recommendation that observations be made on living material (Huhtinen 1990, Baral 1992). The character combinations, however, are remarkable enough to allow recognition based on dead herbarium material alone. The colours are given according to the code of Cailleux (1981). The reagents and colour reactions are abbreviated according to Huhtinen (1990).

\section{Cudoniella viridula Grelet}

- Fig. 1

Material studied: Finland. Satakunta: Punkalaidun, Vanttila, grid $27^{\circ} \mathrm{E} 6790: 282$, on cortex of Pinus, 12.XI.1983 Huhtinen $83 / 415$ (TUR). - France. Loir-et-Cher: Mesland, La Touche, I. 1933 Buisson (PC, holotype).

Apothecia stipitate-turbinate with a long stalk, hymenium strongly convex, up to $300 \mu \mathrm{m}$ in diam; margin deflexed, sharply delimited but not incurved, even to minutely uneven, rarely lobate. Stipe $200-500$ $\mu \mathrm{m}$ long, 30-50 $\mu \mathrm{m}$ wide when dry, equal, smooth, irregularly bent when dry, slightly widened at the extreme base. In fresh material colour first whitish, turning clearly green with age; when dry even juvenile apothecia faintly greenish in all parts, mature apothecia olivaceous throughout (T87, N87), more rarely disc Buff (N80).

Ectal excipulum of textura prismatica, cells on middle flanks elongated, $13-28 \times 4-6 \mu \mathrm{m}, \overline{\mathrm{x}}=17.4 \times$ $4.8 \mu \mathrm{m}(\mathrm{n}=20), \overrightarrow{\mathrm{Q}}=3.6$, prismatic towards margin. Inner excipulum of similar to slightly narrower textura prismatica. Walls in ectal parts $0.4 \mu \mathrm{m}$ thick, $\mathrm{CB}-$, MLZ-, fragmentarily with deep amyloid inclusions; these concentrated to stipe base, becoming sparser upwards. Margin composed of cylindrical hyphal ends, $11-16 \times 2.5-3.0 \mu \mathrm{m}$. In $10 \% \mathrm{KOH}$ excipular cells characterized by dull, roundish vacuoles, in $\mathrm{MLZ}$ these mostly disappear, a few being left as golden inclusions.

Asci $16-23 \times 3.2-4.0 \mu \mathrm{m}, \overline{\mathrm{x}}=20.2 \times 3.6 \mu \mathrm{m}(\mathrm{n}=$ 20), $\bar{Q}=5.7$ in $C B$, eight-spored, cylindrical-clavate, with a conical apex. Apical pore moderately MLZ+. Asci arising from croziers. Some ascal bases rarely with strongly amyloid inclusions, similar to those in the excipulum, fragments of amyloid matter present in subhymenium also.

Spores $4.0-6.2 \times 1.2-1.8 \mu \mathrm{m}, \overline{\mathrm{x}}=4.8 \times 1.3 \mu \mathrm{m}(\mathrm{n}=$ 20), $\mathrm{Q}=3.6$ in $\mathrm{CB}$, cuneiform, aseptate, with two minute guttulae in CB, these highly refractive in $10 \%$ $\mathrm{KOH}$, spores appearing aguttulate in MLZ. 

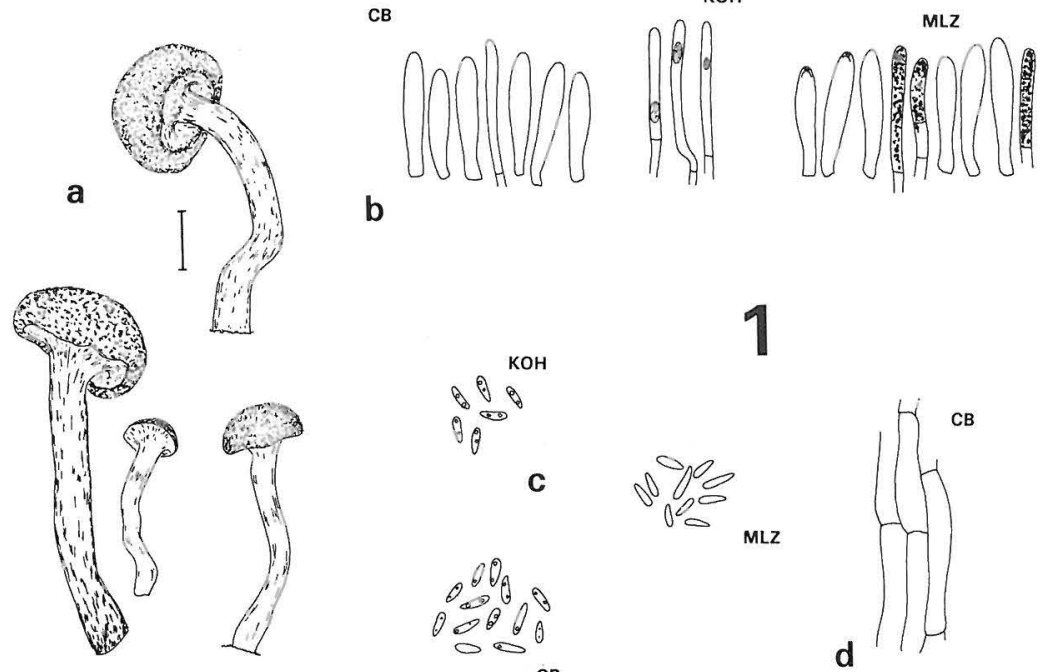

KAR\$SEFNIA 32 (1992)

b
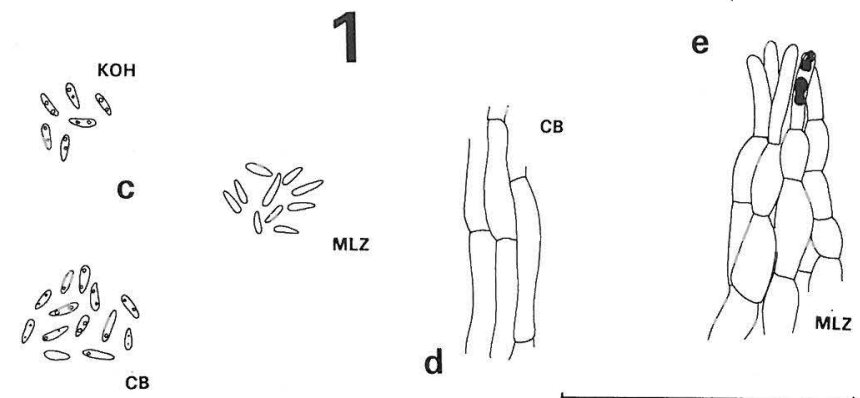

Fig. 1. Cudoniella viridula. a) dry apothecia, b) asci and paraphyses, c) spores, d) ectal excipulum from middle flanks, e) margin. Scale $50 \mu \mathrm{m}$, for apothecia $100 \mu \mathrm{m}$. Specimen S. Huhtinen $83 / 415$.

Paraphyses cylindrical to apically slightly widened, 1.8-2.6 $\mu \mathrm{m}$ wide, containing dull vacuoles in $\mathrm{KOH}$ similar to those in the excipulum, in MLZ ca. 1/ 3 of the paraphyses with distorted, golden yellow contents, strongly cyanophilous and distorted in $\mathrm{CB}$, the contents once strongly amyloid in MLZ.

The original description of Cudoniella viridula (Grelet 1947) matches the present material almost perfectly. The only notable differences are the somewhat stouter apothecia in Grelet's material and the budding of ascopores specifically mentioned and depicted by him. Study of the holotype specimen showed that the type consists of only one, very juvenile apothecium. This was left unmounted. As the type is not empty, $C$. viridula is not neotypified. The new, abundant collection thus allows only an emended description of the species.

The original description of Helotium proximellum P. Karst. matches the present material rather well. A convex hymenium, short stipe and white to greenisholivaceous colours were among the macroscopic characters given by Karsten. A major difference is seen in the ecology: Karsten (1871) gave pine needles as substrate. No original material exists under that name in Karsten's herbarium (in $\mathrm{H}$ ). There are, however, two collections which possibly belong to those cited by Karsten (1871). The collection data and ecology fit the original diagnosis well. Karsten labelled both specimens Peziza tenerrima Fr., a name which he listed under the synonymy of Helotium acuum (Alb. \& Schw.: Fr.) Fr. One convolute is empty, but Karsten has depicted a Cudoniella-like fungus on the front cover. The stipe is shown as fairly long, which is in contrast to the original diagnosis of Helotium proximellum.

The other convolute (Herb. Karsten 2808) bears a sketch of a cup-shaped, subsessile discomycete accompanied by the words "albida vel hyalino alba". Dr. W.-R. Arendholz has determined the collection as Dasyscyphus acuum (Alb. \& Schw. : Fr.) Sacc., and this is apparently the species depicted and observed by Karsten. Thus, neither collection can with certainty be linked to $H$. proximellum, which is best considered a dubious name. Basing his opinion on the description, Carpenter (1981) suggested that the species belongs to Hymenoscyphus S. F. Gray. Peziza tenerrima sensu Karsten embraced two clearly different taxa.

Clements and Shear (1931) lectotypified Cudoniella with C. acicularis (Bull. : Fr.) Schroet., but, as pointed out by Dennis (1963), this had been done by Boudier (1907). Cannon et al. (1985) write of the genus "type not designated". The present day concept of the type species embraces a fungus resembling Grelet's species in the apothecia, excipular structure, marginal structure and spore shape. The differences are found in the volume of the hymenial characters and in the presence of vacuolar pigment in C. viridula. This substance, which in CB and MLZ mounts is seen as totally distorted globules, looks similar to the yellow pigment of $P$ hialina, becoming golden yellow in MLZ. In $10 \% \mathrm{KOH}$ these vacuoles were seen as 

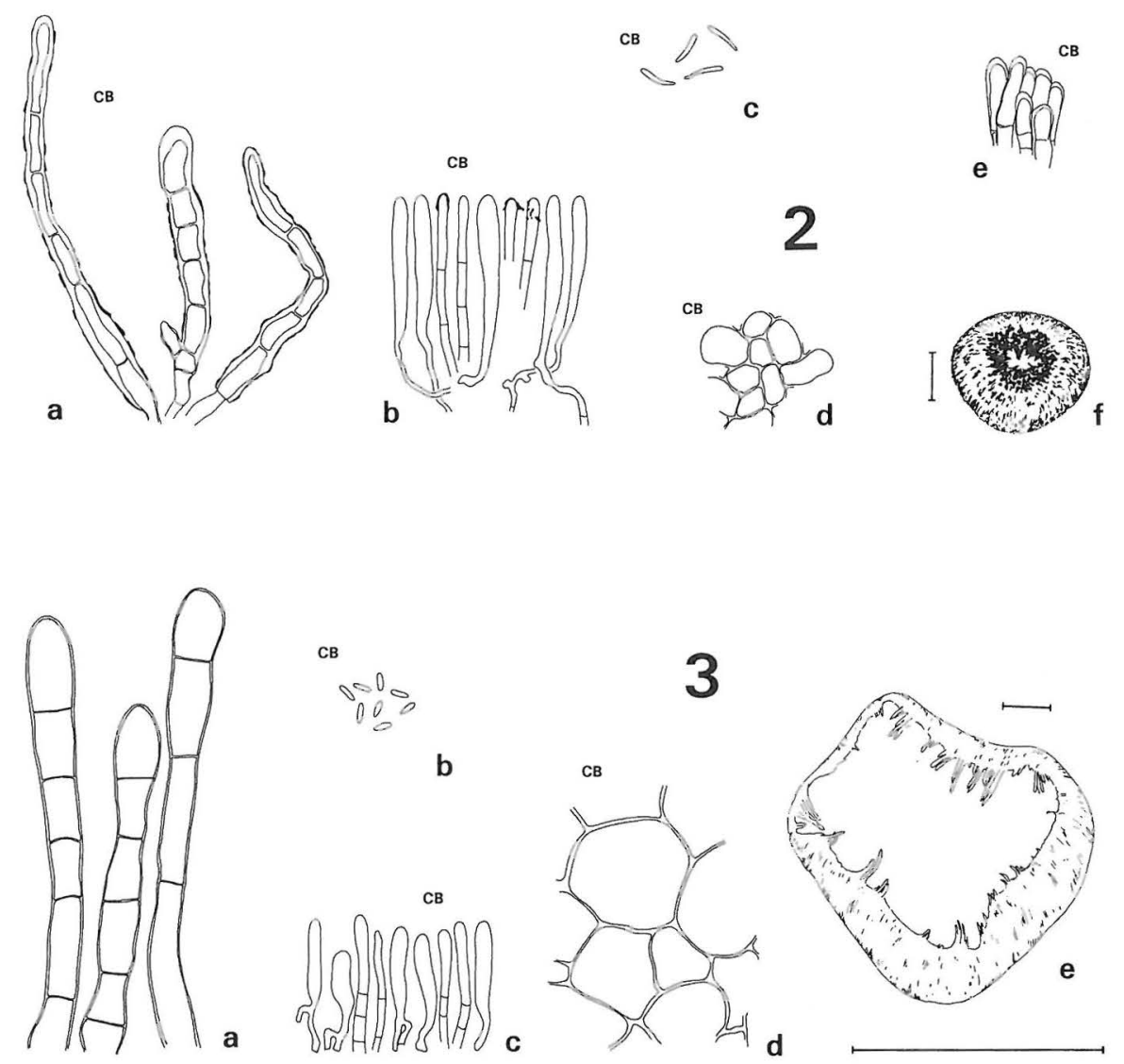

Figs. 2-3. Holotypes of Orbiliaster, scale $50 \mu \mathrm{m}$, for apothecia $100 \mu \mathrm{m}$. -2 : 0 . paradoxa. a) marginal hairs, b) asci and paraphyses, c) spores, d) ectal excipulum from middle flanks, e) margin, f) dry apothecium. - 3: 0 . pilosa. a) marginal hairs, b) spores, c) asci and paraphyses, d) ectal excipulum from middle flanks, e) dry apothecium.

faintly refringent but more regular in shape. Such vacuoles were termed refractive vacuoles by Baral (1989), who emphasized that, although constant and frequent in living material, they are partly lost in herbarium material. Consequently, fresh material of C. viridula is likely to differ markedly in the contents of the paraphyses and marginal hyphal ends.

The spores are regularly guttulate in $\mathrm{CB}$ mounts, whereas in MLZ they appear totally aguttulate. In $10 \% \mathrm{KOH}$ they mostly contain two clearly refringent bodies. These are much more easily observed in this mountant than the larger vacuoles in the paraphyses and at the margin.

The Finnish collection was made from an erect, partly dried conifer trunk fairly late in the season. In spite of repeated frosts the apothecia were growing undamaged under the loose cortex.
Orbiliaster paradoxa sp. nov.

- Fig. 2

Apothecia cupulata, sessilia, in statu vivo usque ad $1 \mathrm{~mm}$ in diametro, minute pilosa, rosea; specimina exsiccata usque ad 0.7 $\mathrm{mm}$ in diametro, ochracea vel armeniaca, margine albopilosa. Excipulum externum textura angulari vel textura globulosa, instructum cellulis circa 6-11 $\times 4-7 \mu \mathrm{m}$, aliquantum crassotunicatis, hyalinis, non amyloideis. Pili 40-85 × 3.5-7.0 $\mu \mathrm{m}$, cylindracei vel irregulariter constricti, crassotunicati, multiseptati, hyalini, in iodo non colorati, leves vel minuter granulosi; granulis cyanophilis. Asci $30-50 \times 2.5-4.0 \mu \mathrm{m}$, octospori, non amyloidei, in basi valde elongati, saepe bifurcati. Sporae 7-9 $71 \mu \mathrm{m}$, tenuiter aciculares vel subfusoideae, aseptatae. Paraphyses cylindraceae vel subclavatae, $2 \mu \mathrm{m}$ latae, cellulis terminalibus 11-25 $\mu \mathrm{m}$ longis, in apice epithecio hyalino, fragmentato, cyanophilo tectae.

Holotype: Finland. Varsinais-Suomi: Parainen, Skräbböle, grid $27^{\circ} \mathrm{E} 66955: 2394$, on inner side of cortex of Populus tremula or Salix, 19.X.1985 Huhtinen 85/157 (TUR 99719). 
Apothecia cupulate, sessile, up to $1 \mathrm{~mm}$ in diam, pink, margin minutely hairy. Ectal excipulum composed of textura angularis-textura globulosa, lacking clear intracellular spaces, walls slightly thickened, cells ca. 6-11 x 4-7 $\mu \mathrm{m}$, hyaline. Hairs $40-85 \times$ $3.5-7.0 \mu \mathrm{m}$, cylindrical, typically slightly constricted at the septa, multiseptate, often glued together; wall hyaline, MLZ-, CB- but covered with a fragmentary cyanophilous layer forming irregular, low warts. Asci 30-50 x 2.5-4.0 $\mu \mathrm{m}$, eight-spored, apex MLZ-, base very long, filiform, often bifurcate.

Spores $7-9 \times 1 \mu \mathrm{m}$, cuneiform, aseptate. Paraphyses cylindrical to subclavate, $2 \mu \mathrm{m}$ wide, terminal cells 11-25 $\mu \mathrm{m}$ long, often apically covered with amorphous, $\mathrm{CB}+$ material.

The genus Orbiliaster was erected by Dennis (1954) to accommodate one tropical species with a resemblance to Orbilia Fr. but with cylindrical paraphyses and clear hairs at the cup margin. Since the type was collected, little has happened in the genus: no new taxa have been described or transfers to the genus proposed.

Recently Spooner (1987) discussed Orbiliaster and suggested, without being able to study the type, that Patinella tenebricosa Svrcek could belong to the genus (Svrček 1977). Unfortunately the type was still unavailable for study, but judging from the description, $P$. tenebricosa may indeed belong to Orbiliaster. The hairs were, however, illustrated as thin-walled, clavate and one-celled. Other differences are found in the apothecial colours, which in $P$. tenebricosa are dark violaceous, whereas the two known species of Orbiliaster have much lighter pigmentation. Seen under the microscope, the excipular cells and hairs were stated to be hyaline to pale brown, whereas in $O$. pilosa and $O$. paradoxa they are hyaline.

Study of the type of the genus (Orbiliaster pilosa Dennis; Trinidad, River Estate, Diego Martin, 22.IX.1949 Dennis 30; K, holotype) resulted in some emendations to Dennis' description (Fig. 3). The paraphyses were found to be clearly wider than those depicted by Dennis. The asci measure $18-26 \times$ 3.0-3.6 $\mu \mathrm{m}$ and are MLZ-. They often arise from a clearly bifurcate base.

Although occurring far apart geographically, $O$. pilosa and $O$. paradoxa are similar and clearly congeneric. The cyanophilous hair wall coating is also seen in the former species, but only in juvenile hairs.
It apparently disintegrates fairly soon and finally disappears. However, mature hairs were studied only on an old mount attached to the type specimen. No epithecium was observed in $O$. pilosa.

Acknowledgements. Dr. Ain Raitviir is warmly thanked for pointing out an affinity to Orbiliaster in one of my drawings of critical specimens. My study was supported financially by the Academy of Finland. Ms. Anna Damström, M.A., is thanked for revising the English text and Prof. Teuvo Ahti for revising the Latin diagnosis.

\section{References}

Baral, H.O. 1989: Beiträge zur Taxonomie der Discomyceten 2. Die Calycellina-Arten mit 4sporigem Asci. - Beitr. Kenntnis Pilze Mitteleuropas 5:209-236.

Baral, H.O. 1992: Vital versus herbarium taxonomy: morphological differences between living and dead cells of Ascomycotes, and their taxonomic implications. - Mycotaxon, in press.

Boudier, E. 1907: Histoire et classification des Discomycètes d'Europe. - 221 pp. Paris.

Cailleux, A. 1981: Code des couleurs des sols. Boubèe.

Cannon, P.F., Hawksworth, D.L. \& Sherwood-Pike, M.A. 1985: The British Ascomycotina. An annotated checklist. 302 pp. Huddersfield.

Carpenter, S.E. 1981: Monograph of Crocicreas (Ascomycetes, Helotiales, Leotiaceae). - Mem. New York Bot. Gard. 33:1-290.

Clements, F.E. \& Shear, C.L. 1931: The genera of fungi. 496 pp., 58 tab. New York.

Dennis, R.W.G. 1954: Some inoperculate discomycetes of tropical America. - Kew Bull. 2:289- 348.

Dennis, R.W.G. 1963: Remarks on the genus Hymenoscyphus S. F. Gray, with observations on sundry species referred by Saccardo and others to the genera Helotium, Pezizella or Phialea. - Persoonia 3:29-80.

Grelet, L.-J. 1947: Les Discomycètes de France d'après la classification de Boudier. - Rev. Mycol. 12:24-36.

Huhtinen, S. 1989(1990): A monograph of Hyaloscypha and allied genera. - Karstenia 29:45-252.

Karsten, P.A. 1871: Mycologia Fennica 1. Discomycetes. Bidr. Känned. Finlands Natur Folk 19:1- 263.

Spooner, B.M. 1987: Helotiales of Australasia: Geoglossaceae, Orbiliaceae, Sclerotiniaceae, Hyaloscyphaceae. - Bibl. Mycol. 116:1-711.

Svrček, M. 1977: New or less known Discomycetes. 5. Nové nebo méne znamé diskomycety. 5. - Ceská Mykol. 31:132-138.

Received on 6 February 1992 